\title{
Profil fitokimia dan aktivitas antibakteri fraksi etil asetat akar jarak pagar (Jatropha curcas Linn.)
}

\author{
Sudarman Rahman ${ }^{*}$, Stevin Carolius Angga1, Erwin Prasetya Toepak ${ }^{1}$, Muhammad Takdir \\ Bachtiar $^{2}$ \\ 1Program Studi Kimia, Fakultas MIPA, Universitas Palangka Raya, Palangka Raya, Indonesia. \\ 2Program Studi Farmasi, Fakultas Farmasi, Universitas Halu Oleo, Kendari, Indonesia.
}

DOI: https://doi.org/10.29303/sjp.v2i2.116

Article Info

Received : 2021-06-30

Revised : 2021-09-29

Accepted : 2021-09-29

\begin{abstract}
Bacterial infections are a major cause of chronic infections and mortality that continues to threaten public health worldwide. Various medicinal plants used in folk medicine have demonstrated wound healing and antibacterial properties. The aims of the study are investigation phytochemical and antibacterial activity of ethyl acetate fraction from jarak pagar roots (Jatropha curcas Linn.). The roots were treated with maceration method using ethanol $70 \%$ and subsequently fractioned to ethyl acetate fraction. The fractions were used for phytochemical screening and antibacterial assay using Kirby and Bauer agar difussion method. The results showed that ethyl acetate fraction jarak pagar roots contained alkaloid, flavonoids, saponins, steroids, poliphenol dan tannins. The antibacterial activity of jarak pagar roots againts Staphylococcus aureus and Escherichia coli shows that the activity of this fraction with concentration $8 \mathrm{mg} / \mathrm{mL}$ has strong inhibitory potency against the growth $S$. aureus with inhibitory zone is $14,3 \mathrm{~mm}$ and has moderate inhibitory potency against $E$. coli with inhibitory zone is $9 \mathrm{~mm}$. The increase concentrations of ethyl asetate fraction jarak pagar roots shows high inhibition diameter of bacterial growth.
\end{abstract}

Keywords: ethyl acetate fraction, jarak pagar roots, antibacterial activity.

Citation: Rahman, S., Angga, S. C., Toepak, E. P., \& Bachtiar, M. T. (2021). Profil fitokimia dan aktivitas antibakteri fraksi etil asetat akar jarak pagar (Jatropha curcas Linn.). Sasambo Journal of Pharmacy, 2(2), 73-79. https://doi.org/10.29303/sjp.v2i2.116

\section{Pendahuluan}

Infeksi bakteri merupakan penyebab utama infeksi kronis dan kematian yang terus mengancam kesehatan masyarakat di seluruh dunia (Kang et al., 2021). Penyakit infeksi ini dapat disembuhkan dengan mengkonsumsi antibiotik. Peningkatan bakteri yang resisten antibiotik menimbulkan ancaman utama bagi kesehatan masyarakat, munculnya Methicillin Resistant Staphylococcus Aureus (MRSA) merupakan salah satu masalah kesehatan yang semakin meningkat di berbagai belahan dunia. MRSA merujuk pada bakteri yang Staphylococcus aureus (S. aureus) yang merupakan bakteri kebal (resisten) atau tidak lagi mempan terhadap antibiotik, seperti methicillin (Kienast et al., 2016). Untuk mengatasi hal tersebut, dibutuhkan antibiotik tambahan dari luar yang bersifat alami.

Seiring dengan perkembangan zaman dan teknologi, tumbuh-tumbuhan dapat digunakan untuk bahan sintesis senyawa kimia dan obatobatan tradisional. Senyawa kimia yang terkandung dalam suatu tanaman memegang peranan penting dalam menunjang kegunaan tanaman tersebut, khususnya sebagai tanaman obat (Nurmuhaimina et al., 2009). Salah satunya adalah pemanfaatan obat tradisional yang dinilai memiliki efek samping lebih 
kecil dibandingkan dengan obat yang berasal dari bahan kimia (Bibitha et al., 2002).

Jarak pagar merupakan tumbuhan yang termasuk dalam kelompok yang dimanfaaatkan sebagai obat tradisional oleh berbagai etnis di Indonesia. Salah satu bagian yang umum digunakan yakni akarnya. Proses pengolahannya, dilakukan secara tradisional dimana akarnya dicuci hingga bersih, ditumbuk hingga halus lalu diberi sedikit air kemudian dioleskan pada bagian tubuh yang sakit (Ruslin \& Sahidin, 2008; Rugayah et al., 2009).

Berdasarkan skrining fitokimia, akar tumbuhan jarak pagar (Jatropha curcas Linn.) mengandung flavonoid, alkaloid, saponin, steroid, dan tanin (Igbinosa et al., 2009). Flavonoid pada tumbuhan herbal memiliki efek antiinflamasi, antialergi, antimikroba, antioksidan, dan efektif untuk beberapa golongan jamur. Sejalan dengan itu, menurut Hodek et al., (2002), flavonoid yang terkandung dalam ekstrak kulit batang jarak memiliki aktivitas biologi seperti antimikroba, anti alergi, dan antioksidan. Senyawa metabolit sekunder juga terdapat dalam ekstrak etanol daun jarak pagar yaitu alkaloid, saponin, tanin, terpenoid, steroid, glikosida, senyawa fenol, dan flavonoid (Sharma et al., 2012).

Kajian farmakologi tumbuhan jarak pagar (Jatropha curcas Linn.) memperlihatkan berbagai aktivitas biologis dimana kulit batang, buah dan daun bersifat antimikroba (Mothana \& Lindequst, 2005). Pengujian aktivitas tersebut belum dalam bentuk senyawa murni tetapi masih dalam bentuk ekstrak jaringan tanaman dari ekstrak metanol daun jarak pagar (Jatropha curcas Linn.) yang dilaporkan mempunyai aktivitas antimikroba (Windarwati, 2011). Penelitian oleh Sharma et al., (2012) menunjukkan senyawa metabolit sekunder ekstrak metanol akar, batang, dan daun J. curcas Linn. menunjukkan aktivitas antibakteri terhadap Staphylococcus aureus dan Escherichia coli. Selain itu, ekstrak etil asetat, n-heksan, dan metanol akar J. curcas Linn. memiliki aktivitas antimikroba terhadap beberapa mikroorganisme penyebab infeksi seksual (Aiyelaagbe et., 2007). Adanya aktivitas antimikroba pada ekstrak jarak pagar dapat dilanjutkan pada pengujian fraksi etil asetat akar jarak pagar (Jatropha curcas Linn.) (Setyaningsih et al., 2014). Berdasarkan uraian di atas, perlu dilakukan skrining fitokimia dan uji aktivitas antibakteri menggunakan fraksi etil asetat akar jarak pagar.

\section{Metode}

\section{Alat dan Bahan}

Alat yang digunakan dalam penelitian ini adalah seperangkat alat gelas $\left(\right.$ Pyrex $\left.^{\circledR}\right)$, rotary evaporator $\left(\right.$ Buchi $\left.^{\circledR}\right)$, blender (Philips $\left.{ }^{\circledR}\right)$, Laminar Air Flow (E-Scientific ${ }^{\circledR}$ ), kertas Whatman 41, neraca analitik (Precisa ${ }^{\circledR}$ ), autoklaf (Daihan Lab Tech ${ }^{\circledR}$ ), bunsen, jarum ose, pinset, rak tabung reaksi, waterbath (Stuart ${ }^{\circledR}$ ) dan Antibiotic Zone Reader.

Bahan yang digunakan dalam penelitian ini adalah etil asetat $\left(\right.$ Merck $\left.^{\circledR}\right)$, etanol 70\% $\left(\right.$ OneMed $\left.^{\circledR}\right)$, $\mathrm{HCl}$ pekat, $\mathrm{FeCl}_{3}$, eter, pereaksi Mayer, Pereaksi Wagner, Pereaksi Dragendorf, dan Pereaksi Lieberman-Buchard, akuades steril (OneMed $\left.{ }^{\circledR}\right)$, spiritus, aluminium foil, nistatin, tetrasiklin, NaCMC 1\% (Food Grade ${ }^{\circledR}$ ), NaCl 0,9\% (Widatra ${ }^{\circledR}$ ), media NA (Nutrient Agar) $\left(\right.$ Merck $\left.^{\circledR}\right)$, NB (Nutrient Broth) $\left(\right.$ Merck $\left.^{\circledR}\right)$, bakteri uji : Staphylococcus aureus ATCC 25923, Escherichia coli ATCC 25922, dan fraksi etil asetat yang diperoleh dari fraksinasi bertingkat ekstrak akar jarak pagar.

\section{Pengumpulan dan Pengolahan Sampel}

Sampel yang digunakan dalam penelitian adalah akar jarak pagar yang berasal dari Hutan Desa Masagena, Kecamatan Konda, Kabupaten Konawe Selatan, Provinsi Sulawesi Tenggara. Akar jarak pagar kemudian dibersihkan menggunakan air dan dikeringkan di bawah sinar matahari hingga kering dengan ditutupi kain hitam. Kemudian akar jarak pagar dibuat menjadi ukuran yang lebih kecil untuk memudahkan pada saat dihaluskan dengan blender hingga menjadi serbuk.

\section{Pembuatan Fraksi Etil Asetat}

Akar jarak pagar (Jatropha curcas Linn.) dicacah lalu diblender sampai halus, sehingga diperoleh serbuk sebanyak $1 \mathrm{~kg}$. Serbuk akar mulamula dimaserasi dengan etanol $70 \%$ sampai semuanya terendam, lalu dibiarkan selama 1×24 jam. Setelah 24 jam, filtrat etanol dikeluarkan dan ditampung. Selanjutnya dengan cara yang sama serbuk dimaserasi lagi dengan etanol yang baru sampai filtrat yang diperoleh tidak berwarna. Filtrat pertama, kedua dan ketiga digabungkan, kemudian dipekatkan dengan rotary evaporator sehingga diperoleh ekstrak kental etanol.

Ekstrak etanol kental diambil $200 \mathrm{~g}$ kemudian dipartisi menggunakan n-heksan:air (3:1) sampai terbentuk dua lapisan yaitu lapisan air dan lapisan n-heksan. Lapisan air diambil kemudian dipartisi dengan etil asetat:air (3:1) sampai terbentuk dua lapisan yaitu lapisan air dan lapisan etil asetat. Kemudian fraksi etil asetat ditampung. Partisi 
dilakukan sebanyak 3 kali. Fraksi etil asetat disatukan kemudian diuapkan menggunakan rotary evaporator sehingga diperoleh fraksi etil asetat kental.

\section{Skrining Fitokimia Fraksi Etil Asetat Akar Jarak Pagar \\ Uji Alkaloid}

Sebanyak 0,1 g fraksi etil asetat dilarutkan dalam $10 \mathrm{~mL}$ kloroform amoniak. Lapisan kloroform diambil kemudian ditambahkan larutan asam sulfat 2 M lalu dimasukkan dalam corong pisah dan dikocok kuat-kuat, didiamkan sampai larutan asam sulfat dan kloroform memisah.

Lapisan asam sulfat diambil dan dibagi 3 tabung, lalu masing-masing tabung diuji dengan:

- Pereaksi Mayer, jika ada endapan putih positif ada alkaloid.

- Pereaksi Wagner, jika ada endapan coklat positif ada alkaloid.

- Pereaksi Dragendorff, jika ada endapan coklat kemerahan positif ada alkaloid.

(Hossain et al., 2013).

\section{Uji Flavonoid}

Sebanyak 0,1 g fraksi etil asetat diekstraksi dengan $10 \mathrm{~mL}$ etanol $80 \%$. Selanjutnya ditambahkan 2,5 mg logam $\mathrm{Mg}$ kemudian dibagi menjadi 2 tabung. Tabung 1 ditambahkan dengan $0,5 \mathrm{~mL} \mathrm{HCl}$ pekat. Warna merah muda, kuning atau jingga menunjukkan adanya flavonoid, tabung kedua digunakan sebagai kontrol (Affandy, 2021).

\section{Uji Saponin}

Sebanyak 0,1 g fraksi etil asetat ditambahkan aquades kemudian dipanaskan hingga mendidih. Kemudian larutan dikocok kuat dan apabila terbentuk busa yang stabil selama \pm 10 menit maka sampel dinyatakan mengandung saponin (Hossain et al., 2013).

\section{Uji Steroid dan Triterpen}

Sebanyak 0,1 g fraksi etil asetat diekstraksi dengan $20 \mathrm{~mL}$ eter. Ekstrak eter diuji dengan pereaksi Liebermann-Burchard. Warna biru atau hijau menunjukkan adanya steroid dan warna merah atau ungu menunjukkan adanya triterpen (Hossain et al., 2013).

\section{Uji Polifenol dan Tanin}

Sebanyak 0,1 g fraksi etil asetat dilarutkan dengan $10 \mathrm{~mL}$ air lalu dididihkan. Larutan air dibagi menjadi 2 bagian, bagian pertama diteteskan dengan larutan $\mathrm{FeCl}_{3}$ (2-3 tetes), jika larutan menjadi biru tua maka menunjukkan adanya tanin/polifenol (Hossain et al., 2013).

\section{Preparasi Uji Antibakteri}

Sterilisasi Alat

Sterilisasi alat dilakukan sebelum semua peralatan digunakan, yaitu dengan cara semua alat dibungkus menggunakan kertas dan disterilkan dalam autoklaf pada $121^{\circ} \mathrm{C}$ dengan tekanan $1 \mathrm{~atm}$ selama 15 menit. Alat yang tidak tahan terhadap panas tinggi disterilkan dengan alkohol $70 \%$ dalam Laminar Air Flow.

\section{Pembuatan Media Agar Miring}

Pembuatan media dilakukan dengan cara $2 \mathrm{~g}$ nutrien agar dilarutkan dalam $100 \mathrm{~mL}$ aquades. Suspensi yang dihasilkan dipanaskan sampai mendidih, kemudian dimasukkan dalam beberapa tabung reaksi masing-masing sebanyak $15 \mathrm{~mL}$ tiap tabung untuk uji antibakteri, dan $5 \mathrm{~mL}$ untuk peremajaan bakteri, kemudian ditutup dengan kapas. Proses ini dilakukan di dekat nyala api. Tabung-tabung tersebut kemudian disterilkan dalam autoklaf pada $121^{\circ} \mathrm{C}$ dengan tekanan $1 \mathrm{~atm}$ selama 15 menit kemudian tabung reaksi yang berisi $5 \mathrm{~mL}$ NA diletakkan dalam posisi miring sampai padat pada suhu ruang.

\section{Pembuatan Stok Kultur}

Diambil satu koloni bakteri uji dengan jarum ose steril, lalu ditambahkan pada media NA miring dengan cara menggores, setelah itu diinkubasi dalam inkubator pada suhu $37^{\circ} \mathrm{C}$ selama $18-24$ jam.

\section{Pembuatan Biakan Aktif}

Dari stok kultur bakteri yang telah tumbuh, diambil koloni bakteri dengan jarum ose steril lalu dibiakkan dalam $10 \mathrm{~mL}$ aquades steril selama satu jam dan dihomogenkan. Larutan ini berfungsi sebagai biakan aktif.

\section{Pembuatan Larutan Natrium CMC 1\% (b/v)}

Sebanyak $1 \mathrm{~g}$ Na-CMC dimasukkan sedikit demi sedikit kedalam $50 \mathrm{~mL}$ aquades hangat sambil diaduk hingga terbentuk larutan koloidal dan dicukupkan volumenya hingga $100 \mathrm{~mL}$ dengan aquades dalam labu takar $100 \mathrm{~mL}$.

\section{Pembuatan Suspensi Tetrasiklin 1\% (b/v)}

Suspensi tetrasiklin dibuat dengan cara $1 \mathrm{~g}$ tetrasiklin yang berbentuk serbuk disuspensikan dalam larutan Na-CMC 1\% sedikit demi sedikit sambil diaduk dan dicukupkan volumenya sampai $100 \mathrm{~mL}$. Setiap akan digunakan dikocok terlebih dahulu. 


\section{Pembuatan Suspensi Kloramfenikol 1\% (b/v)}

Suspensi kloramfenikol dibuat dengan cara $1 \mathrm{~g}$ kloramfenikol yang berbentuk serbuk disuspensikan dalam larutan Na-CMC 1\% sedikit demi sedikit 76egati diaduk dan dicukupkan volumenya sampai $100 \mathrm{~mL}$. Setiap akan digunakan dikocok terlebih dahulu.

\section{Pembuatan Suspensi Fraksi akar jarak pagar}

Fraksi kental etil asetat ditambahkan sedikit aquades dan dipanaskan hingga mendidih, kemudian fraksi etil asetat didinginkan. Fraksi etil asetat ditimbang sesuai dengan konsentrasi yang diinginkan, kemudian disuspensikan dalam NaCMC $1 \% \mathrm{~b} / \mathrm{v}$.

\section{Uji Aktivitas Antibakteri}

Uji aktivitas antibakteri dilakukan terhadap bakteri Staphylococcus aureus dan Escherichia coli dengan menggunakan difusi cakram. Bakteri uji diinokulasikan kedalam media NB (Nutrient Broth) sebanyak 3 jarum ose, dan diinkubasi selama 24 jam pada suhu $37^{\circ} \mathrm{C}$. Suspensi bakteri hasil inokulasi dikocok dengan alat pemutar kemudian disesuaikan dengan standar kekeruhan Mc Farland 0,5. Suspensi bakteri dimasukkan kedalam cawan petri sebanyak 0,1 mL, kemudian ditambahkan medium NA (Nutrient Agar) $10 \mathrm{~mL}$ yang belum membeku, dengan suhu sekitar $40^{\circ} \mathrm{C}$. Selanjutnya digoyanggoyang sampai membeku. Kedalam medium yang berisi bakteri dimasukkan kertas cakram $6 \mathrm{~mm}$ yang telah dicelupkan kedalam larutan fraksi etil asetat dengan konsentrasi 0,$5 ; 2 ; 4 ; 6$; dan $8 \mathrm{mg} / \mathrm{mL}$ serta 76 egativ positif dan 76 egative. Tetrasiklin dan kloramfenikol digunakan sebagai 76 egativ positif serta aquades sebagai 76egativ 76egative.

\section{Hasil dan Pembahasan}

\section{Ekstraksi, Fraksinasi, dan Uji Fitokimia}

Metode ekstraksi yang digunakan dalam penelitian ini adalah maserasi kemudian dilakukan fraksinasi. Metode maserasi dipilih karena pengerjaan dan peralatan yang digunakan sederhana, mudah diusahakan, mampu menarik senyawa-senyawa berkhasiat dan untuk menghindari kerusakan beberapa senyawa aktif dari akar jarak pagar (Latif et al., 2019). Fraksi etil asetat kemudian dipekatkan menggunakan rotary evaporator dan diperoleh fraksi kental etil asetat sebanyak 45,6 g. Hasil partisi $200 \mathrm{~g}$ ekstrak etanol kental dengan menggunakan pelarut etil asetat : air (3:1) disajikan pada Tabel 1.
Tabel 1. Hasil partisi ekstrak etanol akar jarak pagar dengan pelarut etil asetat : air (3:1)

\begin{tabular}{ccc}
\hline $\begin{array}{c}\text { Berat ekstrak } \\
\text { etanol (g) }\end{array}$ & $\begin{array}{c}\text { Volume filtrat } \\
(\mathbf{m L})\end{array}$ & $\begin{array}{c}\text { Berat fraksi } \\
\text { etil asetat }(\mathbf{g})\end{array}$ \\
\hline \multirow{2}{*}{200} & 290 & \\
& 295 & 45,6 \\
& 290 & \\
\hline
\end{tabular}

Uji fitokimia dilakukan dengan metode uji tabung. Berdasarkan hasil uji fitokimia, kandungan metabolit sekunder yang terdapat dalam fraksi etil asetat akar jarak pagar (Jatropha curcas Linn.) adalah senyawa golongan alkaloid, flavonoid, saponin, steroid, polifenol dan tanin. Hasil uji fitokimia dapat dilihat pada Tabel 2.

Tabel 2. Hasil uji fitokimia fraksi etil asetat akar jarak pagar (Jatropha curcas Linn.)

\begin{tabular}{|c|c|c|}
\hline $\begin{array}{l}\text { Senyawa } \\
\text { metabolit } \\
\text { sekunder }\end{array}$ & $\begin{array}{l}\text { Perlakuan/ } \\
\text { pereaksi }\end{array}$ & Hasil \\
\hline Alkaloid & Wagner & $\begin{array}{l}\text { Terbentuk } \\
\text { endapan putih } \\
\text { Terbentuk } \\
\text { endapan coklat } \\
\text { kemerahan } \\
\text { Terbentuk } \\
\text { endapan coklat }\end{array}$ \\
\hline Flavonoid & $\begin{array}{l}\mathrm{HCl} \text { pekat + } \\
\text { logam } \mathrm{Mg}\end{array}$ & $\begin{array}{l}\text { Larutan } \\
\text { berwarna jingga }\end{array}$ \\
\hline Saponin & $\begin{array}{l}\text { aquades } \\
\text { (dipanaskan), } \\
\text { larutan dikocok } \\
\text { kuat } \\
\text { Fraksi vang }\end{array}$ & $\begin{array}{l}\text { Terbentuk busa } \\
\text { selama } \pm 10 \\
\text { menit }\end{array}$ \\
\hline $\begin{array}{l}\text { Steroid } \\
\text { dan Terpenoid }\end{array}$ & $\begin{array}{l}\text { larut dalam eter } \\
+\quad \text { Liebermann } \\
\text { Burchard }\end{array}$ & $\begin{array}{l}\text { Larutan } \\
\text { berwarna hijau }\end{array}$ \\
\hline $\begin{array}{l}\text { Polifenol dan } \\
\text { Tanin }\end{array}$ & $\mathrm{FeCl}_{3}$ & $\begin{array}{l}\text { Larutan } \\
\text { berwarna hitam } \\
\text { pekat }\end{array}$ \\
\hline
\end{tabular}

Uji Aktivitas Antibakteri Fraksi Etil Asetat Akar Jarak Pagar (Jatropha curcas Linn.)

Uji aktivitas antibakteri fraksi etil asetat akar jarak pagar (Jatropha curcas Linn.) dilakukan terhadap bakteri Staphylococcus aureus dan Escherichia coli, dengan variasi konsentrasi ekstrak 0,$5 ; 2 ; 4 ; 6$; dan $8 \mathrm{mg} / \mathrm{mL}$. Selain itu, dalam penelitian ini menggunakan kontrol positif tertrasiklin untuk bakteri gram positif (S. aureus) dan kloramfenikol untuk bakteri gram negatif $(E$. coli). Penggunaan variasi konsentrasi dalam uji aktivitas antibakteri bertujuan untuk mengetahui tingkat keaktifan sampel fraksi akar jarak pagar terhadap penghambatan pertumbuhan koloni 
bakteri. Data hasil uji aktivitas antibakteri fraksi etil asetat akar jarak pagar (Jatropha curcas Linn.) ditunjukkan pada Tabel 3.

Tabel 3. Uji Aktivitas Antibakteri Fraksi Etil Asetat Akar Jarak Pagar

\begin{tabular}{lll}
\hline $\begin{array}{l}\text { Konsentrasi } \\
\text { fraksi }(\mathbf{m g} / \mathbf{m L})\end{array}$ & $\begin{array}{l}\text { Rata-rata diameter zona hambat } \\
(\mathbf{m m})\end{array}$ \\
\cline { 2 - 3 } & S. aureus & E. coli \\
\hline 0,5 & 2,1 & 1 \\
2 & 3,6 & 3,3 \\
4 & 6,2 & 6,3 \\
6 & 8,3 & 7,5 \\
8 & 14,3 & 9 \\
$\begin{array}{l}\text { Kontrol positif } \\
\text { (Tetrasiklin 1\%) }\end{array}$ & 24 & - \\
$\begin{array}{l}\text { Kontrol positif } \\
\text { (kloramfenikol }\end{array}$ & - & \\
$\begin{array}{l}\text { 1\%) } \\
\text { Kontrol negatif } \\
\text { (aquades) }\end{array}$ & 0 & 23 \\
\hline
\end{tabular}

Hasil uji antibakteri fraksi etil asetat akar jarak pagar (Jatropha curcas Linn.) terhadap bakteri Staphylococcus aureus tampak bahwa konsentrasi 0,5; 2; 4; 6; dan $8 \mathrm{mg} / \mathrm{mL}$ menghasilkan diameter daya hambat masing-masing sebesar 2,1 mm, 3,6 mm, 6,2 $\mathrm{mm}, 8,3 \mathrm{~mm}$, dan $14,3 \mathrm{~mm}$. Aktivitas penghambatan fraksi etil asetat terhadap pertumbuhan bakteri meningkat dengan semakin tingginya konsentrasi fraksi. Hal ini disebabkan kuantitas komponen aktif yang bersifat sebagai antibakteri semakin banyak dengan semakin tingginya konsentrasi fraksi sehingga kemampuan fraksi dalam menghambat bakteri Staphylococcus aureus juga semakin besar. Pada konsentrasi $8 \mathrm{mg} / \mathrm{mL}$ menunjukkan penghambatan tertinggi dan tidak jauh berbeda dengan daya hambat kontrol positif yaitu sebesar 24 $\mathrm{mm}$. Berdasarkan ketentuan kekuatan suatu sampel terhadap daya hambat pertumbuhan koloni bakteri yaitu (1) ukuran zona hambat $\geq 20 \mathrm{~mm}$ disebut sangat kuat, (2) zona hambat $10 \mathrm{~mm}$ hingga $<20$ $\mathrm{mm}$ disebut kuat, (3) zona hambat $5 \mathrm{~mm}$ hingga $<10$ disebut sedang, (4) jika zona hambat $<5 \mathrm{~mm}$ bersifat lemah (Timothy et al., 2012). Hasil pengamatan tersebut menunjukkan bahwa fraksi etil asetat akar jarak pagar dengan konsentrasi $8 \mathrm{mg} / \mathrm{mL}$ berpengaruh terhadap pertumbuhan bakteri Staphylococcus aureus dengan diameter daya hambat yang dihasilkan termasuk kategori kuat.

Hasil uji antibakteri terhadap bakteri Escherichia coli menunjukkan bahwa fraksi etil asetat akar jarak pagar (Jatropha curcas Linn.) memiliki diameter daya hambat kurang dari $10 \mathrm{~mm}$ pada setiap konsentrasi. Berdasarkan ketentuan kekuatan suatu sampel terhadap daya hambat pertumbuhan koloni bakteri maka dapat disimpulkan bahwa fraksi etil asetat akar jarak pagar konsentrasi 8 $\mathrm{mg} / \mathrm{mL}$ memiliki daya hambat yang lemah terhadap pertumbuhan bakteri Escherichia coli.

Fraksi etil asetat dengan konsentrasi 8 $\mathrm{mg} / \mathrm{mL}$ mampu menghambat kuat bakteri uji yaitu Staphylococcus aureus dan menghambat sedang pada bakteri uji Escherichia coli. Penelitian oleh Audina (2017) menunjukkan bahwa fraksi etil asetat akar jarak merah menunjukkan adanya aktivitas penghambatan terhadap bakteri Staphylococcus aureus dan Escherichia coli pada konsentrasi 25 dan $50 \mathrm{mg} / \mathrm{mL}$. Bakteri Staphylococcus aureus mewakili bakteri gram positif dan bakteri Escherichia coli mewakili bakteri gram negatif. Penyebab perbedaan aktivitas antibakteri fraksi etil asetat terhadap bakteri gram positif dan bakteri gram negatif adalah perbedaan komponen penyusun dinding sel bakteri tersebut. Bakteri Staphylococcus aureus merupakan bakteri gram positif dengan dinding sel yang relatif sederhana, hanya terdiri dari tiga lapisan, yaitu selaput sitoplasmik, lapisan peptidoglikan, dan lapisan luar yang dinamakan simpai. Sedangkan dinding sel bakteri Escherichia coli mempunyai struktur yang berlapis-lapis dan sangat kompleks (Jawetz et al., 1986).

\section{Kesimpulan}

Berdasarkan hasil penelitian dapat disimpulkan bahwa fraksi etil asetat akar jarak pagar (Jatropha curcas Linn.) mengandung senyawa golongan alkaloid, flavonoid, saponin, steroid, polifenol dan tanin. Berdasarkan uji aktivitas antibakteri, fraksi etil asetat konsentrasi $8 \mathrm{mg} / \mathrm{mL}$ menghambat kuat bakteri Staphylococcus aureus dengan zona hambat $14,3 \mathrm{~mm}$ dan menghambat sedang bakteri Escherichia coli dengan zona hambat $9 \mathrm{~mm}$.

\section{Ucapan Terima Kasih}

Ucapan terima kasih kami ucapkan kepada Kepala Laboratorium Farmasi Fakultas Farmasi dan Kepala Laboratorium Biologi FMIPA Universitas Halu OLeo yang telah membantu dalam penelitian ini. 


\section{Daftar Pustaka}

Affandy, F., Wirasisya, A. D., \& Hanifa, N. I. (2021). Skrining fitokimia pada tanaman penyembuh luka di Lombok Timur. Sasambo Journal of Pharmacy, 2(1), 1-6,

https://doi.org/10.29303/sjp.v2i1.84

Aiyelaagbe, O. O., Adeniyi, B. A., Fatunsin, O. F., \& Arimah, B. D. (2007). In vitro antimicrobial activity and phytochemical analysis of Jatropha curcas roots. Intern. J. Pharmacol., 3(1), 106-110. https://doi :10.3923/IJP.2007.106.110

Audina, M. (2017). Uji aktivitas antibakteri fraksi etil asetat akar jarak merah (Jatropha gossypifolia Linn.) terhadap bakteri Staphylococcus aureus dengan metode difusi cakram. Skripsi. Fakultas Kesehatan. Universitas Muhammadiyah Malang. https://eprints.umm.ac.id/42977/

Bibitha, B., Jisha, V. K., Salitha, C. V., Mohan, S., \& Valsa, A. K. (2002). Antibacterial activity of different plant extracts. Indian Journal of Microbiology, 42(3), 361-363.

Hodek, P., Trefil, P., \& Stiborová, M. (2002). Flavonoids-potent and versatile biologically active compounds interacting with cytochromes P450. Chemico-biological interactions, 139(1), 1-21. https://doi.org/10.1016/s0009-2797(01)00285-x

Hossain, M. A., AL-Raqmi, K. A., AL-Mijizy, Z. H., Weli, A. M., \& Al-Riyami, Q. (2013). Study of total phenol, flavonoids contents and phytochemical screening of various leaves crude extracts of locally grown Thymus vulgaris. Asian Pacific journal of tropical biomedicine, 3(9), 705-710. https://doi.org/10.1016/S2221-1691(13)60142-2

Igbinosa, O.O., Igbinosa, E.O., \& Aiyegoro, O.A. (2009). Antimicrobial activity and phytochemical screening of stem bark extracts from Jatropha curcas (Linn.), African Journal of Pharmacy and Pharmacology, 3(2), 58-62. https://citeseerx.ist.psu.edu/viewdoc/downloa $\underline{\mathrm{d} \text { ?doi }=10.1 \cdot 1.561 .1288 \& \mathrm{rep}=\mathrm{rep} 1 \& \text { type }=\mathrm{pdf}}$

Jawetz, E., Melnick, J. L., \& Adelberg, E. A. (1986). Mikrobiologi Kedokteran, Edisi XXII, 317-327, Penerbit Salemba Medika, Jakarta.
Kang, J. H., Kim, M., \& Yim, M. (2021). FXR/TGR5 mediates inflammasome activation and host resistance to bacterial infection. Biochemistry and biophysics reports, 27, 101051.

https://doi.org/10.1016/j.bbrep.2021.101051

Kienast, M. E., Giacoboni, G., \& Lopez, C. (2016). Methicillin Resitant Staphylococcus Auereus (MRSA): Preliminary results in tranning thoroughbreds from Argentina. Journal of Equine Veterinary Science, 39(supplement), 33-44. https://doi.org/10.1016/j.jevs.2016.02.096

Latif, R. A., Wewengkang, D. S., \& Rotinsulu, H. (2019). Uji daya hambat organisme laut spons Amphimedon sp. terhadap pertumbuhan bakteri Staphylococcus aureus, Escherichia coli, dan jamur Candida albicans. Pharmacon, 8(3). https://doi.org/10.35799/pha.8.2019.29331

Mothana, R. A., \& Lindequist, U. (2005). Antimicrobial activity of some medicinal plants of the island Soqotra. Journal of ethnopharmacology, 96(1-2), 177-181. https://doi.org/10.1016/j.jep.2004.09.006

Nurmillah, O. Y,. Liyana-Pathiranan, C. M., \& Shahidi, F. (2011). Isolasi dan identifikasi senyawa kimia ekstrak akar tanaman jarak pagar (jatropha curcas linn.) serta uji aktivitasnya sebagai antibakteri dan antifungi. Journal of Applied Microbiology, 7(2), 142-148.

Nurmuhaimina, S. A., Maulia, R., Yuniarti, I., \& Umaningrum, D. (2009). Uji aktivitas antioksidan dari ekstrak campuran tumbuhan alang-alang (Imperata cylindrica) dan lidah ular (Hedyotis corymbosa) sebagai peredam radikal bebas asam linoleat. Jurnal Ilmiah Berkala Sains dan Terapan Kimia, $\quad 4(1)$ 85-92. http://dx.doi.org/10.20527/jstk.v3i1.2031

Rugayah, R., Sunarti, S., \& Djarwaningsih, T. (2009). Keanekaragaman tumbuhan dan potensinya di Cagar Alam Tangale, Gorontalo. Jurnal Teknologi Lingkungan, 10(2), 21-27. https://doi.org/10.29122/jtl.v10i2.1490

Ruslin, R., \& Sahidin, I. (2008). Identifikasi dan determinasi tanaman obat tradisional masyarakat Sulawesi Tenggara pada Arboretum Prof. Mahmud Hamundu Universitas Haluoleo. Majalah Farmasi Indonesia, 19(2), 101-107. 
Sharma, A.K., Gangwar, M., Tilak, R., Nath, G., Sinha, A.S.K., Tripathi, Y. B., \& Kumar, D. (2012). Comparative in vitro antimicrobial and phytochemical evaluation of methanolic extract of root, stem and leaf of Jatropha curcas Linn. Pharmacognosy Journal, 4(30), 34-40. https://doi.org/10.5530/pj.2012.30.7

Timothy, S.Y., Lamu, F. W., Rhoda, A. S., Adati, R. G., Maspalma, I. D., \& Askira, M. (2012). Acute toxicity, phytochemistry and antibacterial activity of aqueous and ethanolic leaf extracts of Cassia alata Linn. International Research Journal of Pharmacy, 3(6), 73-76. https://irjponline.com/admin/php/uploads/11 69_pdf.pdf

Windarwati, W. (2011). Uji Aktivitas Antimikroba Ekstrak Metanol Daun Tumbuhan Jarak Pagar (Jatropha curcas Linn.) Skripsi. Fakultas MIPA Universitas Halu Oleo. 